\title{
LESSON STUDY AS AN EFFORT TO IMPROVE TEACHER'S PEDAGOGICAL COMPETENCE IN SMP AND MTs 2 MUHAMMADIYAH AIMAS IN THE TIME OF COVID-19
}

\author{
Hidayatussakinah, Ismail Marzuki, and Syamsulrizal \\ Muhammadiyah University of Education Sorong \\ sakinahunimuda@gmail.com
}

\begin{abstract}
This study aims to explain lesson study as an effort to improve teacher pedagogy at SMP Muhammadiyah Aimas and MTs teachers. Muhammadiyah 2 Aimas. The research method used is descriptive qualitative. The research subjects were 10 teachers who were involved from two schools. Data collection techniques used are observation, interviews and documentation. The data analysis technique used Mills and Huberman. The results showed that the principle of lesson study increased the pedagogical competence of teachers of SMP and MTs 2 Muhammadiyah Aimas compared to conventional learning principles. The planning stage (Plan) shows increased collaboration between teachers, creative teachers in choosing and using media that are closer to students' lives, and teachers are getting better at creating a didactic atmosphere in the learning planning process. The learning stage (Do) shows an increase in student activity in learning, the teacher is maximal as a facilitator, the teacher feels challenged by the presence of the observer, the teacher feels helped by the observer, the teacher is more creative, and student responses are higher when carrying out learning. The evaluation stage (See) shows the increasing ability of teachers in evaluating learning outcomes. There are collaborative efforts from the planning, implementation stages to make the evaluation stage maximal and measurable. and higher student response when carrying out learning. The evaluation stage (See) shows the increasing ability of teachers in evaluating learning outcomes. There are collaborative efforts from the planning, implementation stages to make the evaluation stage maximal and measurable. and higher student response when carrying out learning. The evaluation stage (See) shows the increasing ability of teachers in evaluating learning outcomes. There are collaborative efforts from the planning, implementation stages to make the evaluation stage maximal and measurable.
\end{abstract}

Keywords: Lesson Study, Teacher Pedagogy, Teacher Competence

\section{INTRODUCTION}

The quality of graduates from junior high school (SMP) or equivalent cannot be separated from the teacher's role as a source of learning. The teacher is the main learning resource in the teaching and learning process in the classroom. According to law number 14 of 2005 concerning teachers and lecturers, it is stated that teachers are professional educators with the main task of educating, teaching, guiding, directing, training, assessing, and evaluating students. All of the teacher's professional duties cannot be separated from what is called pedagogical competence. Pedagogy is the ability of teachers to understand students, design and implement learning, evaluate learning outcomes, and develop students to actualize their various potentials.

On the one hand, the development of situations and conditions of the times that continue to change from time to time and from generation to generation requires teachers to be creative and innovative in carrying out learning so that they can answer students' problems in their lives. (Hidayatussakinah, Marzuki, \& Ulfa, 2021). The measure of creativity and innovation carried out by teachers cannot be separated from the pedagogical competence of a teacher. 
The existence of Covid-19 which began in early 2020 until now challenges the competence of teachers and must adjust based on the situation and conditions. Where previously learning was carried out offline, it turned into online and forced teachers to master technology as a means of knowledge transfer. Not only that, various learning problems arise during its implementation. Therefore, a strategy or model for developing teacher pedagogy is needed so that it can improve teacher pedagogy during the Covid-19 period.

The above learning problems during the Covid-19 period were also experienced by teachers of SMP and MTs 2 Muhammadiyah Aimas, Sorong Regency, West Papua. Where teachers find it difficult to carry out interesting and innovative learning. So it requires teachers to improve pedagogical competence in carrying out learning.

Seeing the problems experienced by middle school and MTs 2 teachers above, lesson study can be used as a solution in improving teacher pedagogy. Lesson Study is a model of teacher development in improving teacher performance which is carried out jointly by a group of teachers in order to realize teacher performance in a better direction. The principle of lesson study in its implementation is divided into three, namely planning learning (Plan), implementing learning and observing (Do), and carrying out learning reflection (See). These three stages are carried out jointly by the teacher. According to(Tedjawati, 2011)lesson study is very useful in learning and can improve teacher competence in teaching. Hall similarly expressed (Rizki, 2014) that the planning and implementation of lesson study-based learning is better than the conventional one.

Research on improving teacher pedagogical competence with certain models of teachers has already been carried out. First, research (Palettei \& Sulfemi, 2019) with the title The Effect of Teacher Working Groups (KKG) on Improving Pedagogic Competence. The results of this study indicate that there is a positive effect of KKG activities on increasing teacher pedagogic competence. Second, research(Rusilowati, 2012)with the title Development of Characterized Better Teaching And Learning Learning Models to Equip the Pedagogical Competence of Prospective Teacher Students. The results of this study stated that the BTL-K learning model developed had met the criteria of validity, effectiveness, practicality and was able to improve teacher pedagogy.

The difference between this study and the two studies lies in the use of methods or approaches to developing teacher pedagogy. One uses the Teacher Working Group (KKG) approach, and the other uses the Characterized Better Teaching and Learning (PBTLB) approach, while in this study using the Lesson Study method or approach. The similarity between this research and the two studies above is that they both develop teacher pedagogy.

This research is important to do for several reasons. 1) The Covid-19 condition is a condition that places teachers and students not meeting directly and challenging teacher pedagogy in teaching so that it must be improved. 2) There is no pedagogical development model for teachers in SMP and MTs Muhammadiyah Aimas Kab. push. 3) The pedagogical competence of teachers must be improved because the teacher is the main source of learning. 4) The development of human resources for educators, especially the development of teacher pedagogy, is an effort to prepare teachers to have various insights, knowledge, skills, and provide confidence to carry out their duties and obligations as professional officers.

Based on the reasons above, this research is expected to be able to improve the pedagogical competence of teachers in accordance with the mandate of law number 14 concerning teachers. The expected pedagogical sub-competencies are: 1)Understanding students in depth which 
includes understanding students by utilizing the principles of cognitive development, personality principles, and identifying students' initial teaching provisions. 2) Designing learning, including understanding the educational foundation for the benefit of learning which includes understanding the educational foundation, applying learning and learning theory, determining learning strategies based on the characteristics of students, competencies to be achieved, and teaching materials, as well as preparing learning plans based on the chosen strategy. 3) Carry out learning which includes arranging learning settings and carrying out conducive learning. 4) Design and implement learning evaluations which include designing and carrying out evaluations (assessment) of learning processes and outcomes on an ongoing basis with various methods, analyzing the results of evaluation of processes and learning outcomes to determine the mastery level of learning, and utilizing the results of learning assessments to improve program quality. learning in general. and 5) Developing students to actualize their various potentials includes facilitating students to develop various academic potentials, and facilitating students to develop various non-academic potentials.

\section{METHOD}

The method used in this research is descriptive qualitative which aims to explain the process of improving teacher pedagogy through lesson study. The place of research is in the Muhammadiyah Aimas Middle School and Mts. Muhammadiyah 2 Aimas. The research subjects were 10 teachers who applied lesson study in learning for one month (August 2021). Data collection techniques used observation, interviews and documentation. The data in this study are the researcher's notes in the form of words and sentences related to the research problem. The data analysis technique used is the Mills and Huberman model.

\section{DISCUSSION}

Pedagogical competence in this study is seen from three aspects that are applied in three stages of lesson study, namely Plan (learning planning), Do (learning and observation), and See (reflection on learning outcomes. The three pedagogical aspects in question are: First, learning planning and understanding characteristics of students (PLAN), Second, the implementation of learning and student development (DO), Third, evaluation of learning outcomes and reflection (SEE).

This research was conducted during the Covid-19 pandemic. There are two modes used in this research process, namely online and offline modes. The percentage of online mode is $60 \%$ and offline is $40 \%$. Three activities were carried out during the research, namely learning planning activities, opening classes, and reflecting on learning outcomes.

The discussion of the research results is grouped into three findings, namely: 1) teacher's ability to plan learning, 2) teacher's ability to carry out learning, and 3) teacher's ability to evaluate learning outcomes. The three findings are a form of improving teacher pedagogy using the principles of lesson study.

\subsection{Teacher's Ability to Plan Learning (PLAN)}

Based on the results of data analysis on the ability of teachers to plan lessons, several subfindings were found:

\section{a. Cooperation between teachers is increasing in planning lessons}

Good cooperation and collaboration in using the principle of lesson study is very important in its implementation. This good cooperation can be seen from the discussions that flow continuously in the discussion groups. This condition begins when entering the second week of preparing the learning design. All provide constructive opinions on the planned 
learning topics. Starting from offering a built didactic situation, predicting student responses, and planned teacher assistance. They realize that lesson study is different from conventional planning concepts where each individual plans or makes lesson plans independently. But in the concept of lesson study, lesson plans or learning designs are shared property and are done together.(Susilo, 2013). When conducting interviews with the teachers involved, they said that the lesson design/learning plans that were made before opening the class were a shared responsibility, so they had to be arranged as well as possible.

\section{b. Teachers are increasingly creative in choosing and using media that are closer to students' lives}

Choosing the right media to be used in learning will determine student responses. Based on observations when planning using conventional concepts, teachers are not too creative and tend to be lazy in choosing and using learning media. Some even say that they only use textbooks in teaching. However, when using lesson study, teachers feel challenged to use the right media. Exactly in this case what is meant is media that is able to turn on the learning atmosphere. Through lesson study, teachers feel challenged to use media that are close to the lives of students(Leary \& Sherlock, 2020). Teachers realize that the right media is media that is close to the lives of students, so that the classroom atmosphere is more lively and students are more interactive in the learning process.(Syamsulrizal; Sahidi, 2019)

\section{c. Teachers are getting better at creating a didactic atmosphere for students to be taught}

Creating a didactic atmosphere will determine student responses in the learning process. Based on the observations during the discussion, the teacher is getting more creative in creating a didactic learning center. This condition is seen when the teachers determine the didactic atmosphere they build. They said when interviewed, creating a clear and measurable didactic atmosphere was the initial picture of the success or failure of a lesson. Even the teachers involved said that the didactic atmosphere was a challenge when planning lessons. Even in the learning planning process, discussions about the didactic situation that will be carried out require a lot of time for a didactic atmosphere. They realized that this greatly determines the prediction of student responses in the learning process.(Nikolopoulou, Gialamas, \& Lavidas, 2021).

\subsection{Teacher's Ability to Implement Learning (DO)}

The ability to carry out learning as a measure of whether or not the teacher's pedagogical competence increases in managing the classroom in the learning process. In-depth observation of the learning process carried out by the teacher is needed to see the teacher's ability to carry out learning as a form of execution of the plans that have been prepared previously. No matter how good the planning, if it is not implemented it becomes something that is not useful and useful(Habibullah, 2012).

Based on the results of data analysis on the teacher's ability to carry out learning, several subfindings were found.

\section{a. Students are seen to be more active in the learning process}

Student activity and response are very important in measuring the success of a teacher in managing the classroom(Aura, Hassan, \& Hamari, 2021). It can be said that the lonely or the 
vacuum class is the unsuccessful class. Based on the results of class observations, student responses when the teacher asked something related to the subject matter were very enthusiastic. The class is getting busier with various responses and answers from students. Teachers also feel that students' activeness increases when teaching using the principle of lesson study, where students feel well facilitated during learning. Even students who previously did not like to talk became brave to ask and respond.

\section{b. The teacher becomes the maximum facilitator in the classroom}

The teacher being a facilitator is the main job when opening a class(Widi Purwianingsih, 2010). Based on the results of observations in the classroom, the teacher becomes a very maximum facilitator. This can be seen from the stages of learning that are carried out very actively and fun. Teachers really look ready to teach and develop students' abilities. This is due to careful preparation. Starting from determining the topics, materials, media, methods, and learning models used. The results of the interviews also show that teachers are more prepared to teach than conventional teaching methods. The details of the learning are also directed at the learning objectives to be achieved.

\section{c. Teachers are increasingly enthusiastic about carrying out learning with the presence of observers}

The presence of observers in learning becomes a very basic difference when using the principles of lesson study. The presence of observers in learning is not to find fault with the model teacher, but to see student activities in the learning process(Anggara \& Chotimah, 2012). Judging from the results of observations, the model teacher is increasingly enthusiastic about carrying out learning with the presence of an observer. It has become common knowledge that observers are present in the classroom to observe student activities and see the achievement of learning that has been planned at the planning stage (plan). Based on the results of interviews with model teachers, the presence of observers is a challenge in carrying out learning. The presence of the observer at the beginning may be a problem for the model teacher. However, with the observer, the model teacher is more enthusiastic in opening the class. From the observations of the whole class that was opened, the teacher's pedagogical ability was increasing.

\section{d. Teachers find it helpful in seeing student activities with the presence of an observer}

The presence of observers (other teachers in the class during learning) helps the model teacher in seeing student activities. This is what distinguishes the principle of lesson study learning is different from conventional learning principles(Alamri, 2020). Student learning activities, both positive and negative, are seen with the help of observers and make it easier for model teachers to evaluate learning outcomes that have been carried out with students. From the results of interviews with both model teachers and observers, holding classes together is a very good learning resource to improve student learning outcomes.

\section{e. Teacher assistance is very creative in the learning process}

Teacher assistance in the learning process is an explanation, description or certain media that can understand students. From the observations, the principle of lesson study can improve the ability of teachers to provide assistance to students. Teachers not only use language that is easily understood by students but is able to arouse students' interest in participating in the learning process. This can be seen from the response of students who are very cooperative in 
the classroom when learning takes place. Judging from the results of the interviews, the teacher tried to explore the aids that would be used to assist students in learning. So that the learning objectives can be achieved. From these findings, it can be said that lesson study is able to increase teacher assistance to students compared to conventional learning principles(Wolthuis, van Veen, de Vries, \& Hubers, 2020).

\section{f. Student response is getting higher in following the learning process}

Student responses and responses in the learning process are evidence of a live and active class. From the observations, students are more active in speaking and discussing when the teacher uses the principle of lesson study compared to conventional learning. Lesson study is able to explore and develop students' potential through sharing tasks and jumping tasks given by the teacher(Skott \& Møller, 2020). The results of the interviews also concluded that students were more active in responding and discussing using the principle of lesson study. This is influenced by the maximum lesson planner before the class opens. That is, the teacher really prepares all the activities that will be carried out by students. Student responses are higher than conventional learning. The teacher feels that the assistance that has been prepared when preparing the lesson plan has succeeded in growing the enthusiasm and motivation of students to learn.

\subsection{Teacher's Ability to Evaluate Learning (SEE)}

Evaluation of learning outcomes is needed to determine whether certain learning models can improve learning outcomes or not. So that the goals that have been set can be achieved in the implementation of learning.

The principle of lesson study learning makes reflection a very important part to see learning outcomes together(Wolthuis et al., 2020). This has implications for improving the pedagogy (learning management) of teachers in the next lesson.

Based on the results of data analysis, the ability of teachers to evaluate learning outcomes is increasing when using the principles of lesson study. This can be seen when the teachers reflect on the learning that has been done. Sharpness of observation and understanding of student characteristics can be seen through student activities when following the learning process. Both in the planning stage of learning and when opening the class.

The model teacher felt that the evaluation of the learning carried out was very maximal because it helped to see the overall learning that had been done. This is due to efforts to help each other and build teaching competence when using the principle of lesson study assessment.

The pedagogical competence of model teachers and observers increases after reflecting as a form of learning evaluation that has an impact on better classroom management in the next lesson.

Based on observations, evaluation of learning outcomes using the principle of lesson study is more effective than conventional assessments that are more individual. Evaluation of learning outcomes is carried out after learning is carried out together. The existence of collaboration or togetherness starting from the planning stage, the implementation of learning makes the evaluation stage (through reflection) maximal and measurable(Skott \& Møller, 2020). This is the ideal evaluation, where the evaluation is carried out immediately after the learning is carried out.

From the results of interviews with teachers, it is also concluded that evaluations carried out together are much better than evaluations independently. When evaluating student activities, one teacher to another has different points of view in the assessment of learning. This makes the results of the learning evaluation more in-depth and reveals learning facts that can be used 
as the next lesson. This process then becomes a learning arena or a place to improve the pedagogical competence, professionalism, and personality of the teacher.

\section{CONCLUSION}

From the discussion above, it can be concluded that,

a. The ability of SMP Muhammadiyah Aimas and MTs teachers. Muhammadiyah 2 Aimas in planning learning (Plan) improved rapidly when using the principle of lesson study. Lesson study is able to increase collaboration between teachers, be creative in choosing and using media that are closer to students' lives, and teachers are getting better at creating a didactic atmosphere in the learning planning process.

b. The ability of the teachers of SMP Muhammadiyah Aimas and MTs. Muhammadiyah 2 Aimas in carrying out learning (Do) increases when using the principle of lesson study. The principle of lesson study learning is able to increase student activity in learning, the teacher is maximal as a facilitator, the teacher feels challenged by the presence of the observer, the teacher feels helped by the observer to see student learning activities, the teacher is more creative and the student response is higher when carrying out learning.

c. The ability of the teachers of SMP Muhammadiyah Aimas and MTs. Muhammadiyah 2 Aimas in evaluating learning outcomes (See) using lesson study is increasing, because the evaluation is carried out directly after the learning is carried out. There are collaborative efforts from the planning, implementation stages to make the evaluation stage maximal and measurable.

\section{REFERENCES}

Alamri, NM (2020). The Implementation of the Lesson Study Strategy in Teaching Mathematics: Teachers' Perspectives. Education Research International, 2020(1). https://doi.org/10.1155/2020/1683758

Anggara, R., \& Chotimah, U. (2012). Application of Lesson Study Based on Subject Teacher Deliberation (MGMP) to Improve Professional Competence of Civics Teachers in Junior High Schools in Ogan Ilir Regency. Journal of Social Forums, 5(2), 188-197.

Aura, I., Hassan, L., \& Hamari, J. (2021). Teaching within a Story: Understanding the storification of pedagogy. International Journal of Educational Research, 106(January), 101728. https://doi.org/10.1016/j.ijer.2020.101728

Habibullah, A. (2012). Teacher Pedagogic Competence. EDUKASI: Journal of Religious and Religious Education Research, 10(3). https://doi.org/10.32729/edukasi.v10i3.169

Hidayatussakinah, H., Marzuki, I., \& Ulfa, NA (2021). IMPROVEMENT OF CRITICAL THINKING ABILITY THROUGH PROBLEM-BASED LEARNING MODEL. Biolearning Journal. https://doi.org/10.36232/jurnalbiolearning.v8i1.892

Leary, MP, \& Sherlock, LA (2020). Service-Learning or Internship: A Mixed-Methods Evaluation of Experiential Learning Pedagogies. Education Research International, 2020. https://doi.org/10.1155/2020/16832270

Nikolopoulou, K., Gialamas, V., \& Lavidas, K. (2021). Habit, hedonic motivation, performance expectancy and technological pedagogical knowledge affect teachers' intention to use mobile internet. Computers and Education Open, 2(March), 100041. https://doi.org/10.1016/j.caeo.2021.100041

Palettei, AD, \& Sulfemi, WB (2019). The Influence of the Teacher Working Group (KKG) on Improving Pedagogic Competence and Scientific Writing Ability. JPDI (Journal of Indonesian Basic Education), 4(2), 53. https://doi.org/10.26737/jpdi.v4i2.1522

Rizki, S. (2014). Effect of Lesson Study on Improvement. Journal of Mathematics Education FKIP Univ. Muhammadiyah Metro, 3(1), 17-27. 
Rusilowati, A. (2012). Development of Characterized Better Teaching and Learning Learning Models to Equip the Pedagogical Competence of Prospective Teacher Students. Journal of Educational Research Unnes, 29(2), 124710. https://doi.org/10.15294/jpp.v29i2.5649

Scott, CK, \& Møller, H. (2020). Adaptation of lesson study in a Danish context: Displacements of teachers' work and power relations. Teaching and Teacher Education, 87, 102945. https://doi.org/10.1016/j.tate.2019.102945

Susilo, H. (2013). Lesson Study as a Means of Improving Educator Competence. PLEASE 2013 Seminar And Workshop At Aletheia College of Theology Jalan Argopuro 28-34, 132.

Syamsulrizal; Shahidi. (2019). Optimizing the Ability of Mathematics Subject Teachers at SMP/MTs Muhammadiyah in Sorong Regency in Compiling Student Activity Sheets Based on the 2013 Curriculum. Journal of ABDIMAS Community Service, 2(1), 31-36. Retrieved from https://unimuda.e-journal.id/jurnalabdimasa/article/view/400

Tedjawati, J. (2011). Improving Teacher Competence Through Lesson Study: A Case in Bantul Regency. Journal of Education and Culture, 17(4), 480. https://doi.org/10.24832/jpnk.v17i4.43

Widi Purwianingsih, NYR and SR (2010). KNOWLEDGE OF pedagogical content (PCK) and its urgency in TEACHER EDUCATION Widi Purwianingsih*, Nuryani Y. Rustaman** and Sri Redjeki Graduate School, Universitas Pendidikan Indonesia. Journal of Mathematics and Natural Sciences Teaching, 15.

Wolthuis, F., van Veen, K., de Vries, S., \& Hubers, MD (2020). Between lethal and local adaptation: Lesson study as an organizational routine. International Journal of Educational Research, 100(January), 101534. https://doi.org/10.1016/j.ijer.2020.101534 